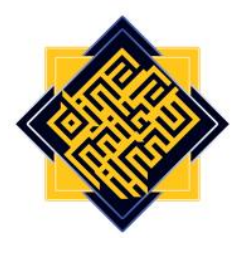

\title{
The Principles of Educational Leadership in the Perspective of the Qur'an
}

\author{
Sa'dullah Assai'di \\ Islamic University Nahdlatul Ulama (UNISNU) Jepara, Indonesia \\ e-mail:sadullah@unisnu.ac.id
}

Abd. Hamid

Islamic University Nahdlatul Ulama (UNISNU) Jepara, Indonesia

e-mail: hamid.abduooo@gmail.com

Subaidi

Islamic University Nahdlatul Ulama (UNISNU) Jepara, Indonesia

e-mail:subaidi@unisnu.ac.id

\begin{abstract}
Humans as inheritors of the earth regulate life and everything. With their intellects and skills, they can make the earth a place to carry out various daily activities. As the caliphs, they get the trust that must be implemented on the earth. In this study, the authors would adopt the cornerstone principles of leadership education in general and in view of the Quran. Principles of leadership in general education studied were those of integrative and cooperative capacity, rationality and objectivity, adaptability and flexibility, delegation, pragmatism, and exemplary. On average, the principles of educational leadership in the perspective of the Our'an are the principle of tawhid, deliberation, fairy, freedom, upright, commanding the good and forbidding the evil, and a good example. From these two principles of educational leadership, they include the education for a leader who according to the morality of the Qur'an (1) is tolerant, (2) likes to do deliberation in decisionmaking, (3) is fair in terms of law, (4) gives freedom, (5) can be trusted, (6) is always doing good, and (7) gives good examples. An educational leader as stated in the Qur'an is the one who upholds Islamic values and leadership principles.
\end{abstract}

Keywords: education and Qur'an, educational leadership, Islamic values 


\section{Sa'dullah Assai'di et al.}

\section{A. Introduction}

Humans as the caliph on the earth regulate life and anything on it. With their intellects and skills, they can make the earth a place to carry out various daily activities (llyas, 2016). As the caliphs, they get the trust that must be implemented on the earth. Likewise, humans are the ulil amri (rulers) who are given the authority to lead themselves or others who possess good characteristics, attitudes, and principles to manage others since leadership is one's ability in influencing and motivating others to do something according to the common goals (Rozak, 2014; Taufikin, 2021).

In management science, a leader plays a vital role in his actions to succeed in the organizational goals If a community, a nation, and a state are led by someone with characteristics, concepts, and principles as stated in The Qur'an, the organizational goals will be brought to success in the world and the hereafter (Ilyas, 2016). The Qur'an is a comprehensive holy book serving as the main source for cultures, knowledge, and sciences wherein, there are unity and coherence of purpose. When The Qur'an describes the universe, for instance, at the same time it is constructing the foundation of faith and noble characters. The Qur'an is impossible to be separated from the religious and social life discourse since it is able to respond to any forms of social dynamics that occur in every era (Al-Ayubi, 2011).

The Prophet as a kamil person serves as the bearer of the last treatise blessed by Allah SWT in various fields, including leadership. He succeeded in urging ignorant people during the Jahiliyah time to become Muslims who were not free from the style and model of the Prophet's leadership. Therefore, we can imitate his leadership to be implemented at present (Ahmad, 2015).

The principles of leadership in Islam actually possess very strong and firm bases. It is not only built by transcendental values but also was practiced centuries ago by the Prophet Muhammad SAW, his companions, and Al-Khulafa' Al-Rasyidin. The foothold from the Quran and hadiths and various empirical evidence has placed the concept of Islamic leadership as one of the leadership models recognized and admired by the international world (Zuhdi, 2014). Leadership in the educational world is also important, since in it a lot of people depend on their success in life, either in the life in the world or the hereafter by searching for knowledge in the educational institution (Subhan, 2017). Educational institutions emerging at present need leaders who may captain the institutional ships so that they may accompany their children to reach their programmed ideals (Ushansyah, 2016).

The verses of the Qur'an supported by the hadiths and historical evidence above become true evidence that the Qur'an, although it implicitly does not mention the word leadership, has given hints of the necessity and the importance of leadership in a social community. In the various existing dictions, the term leadership in the Qur'an is not absolute, meaning that other terms are various in nature. All of the terms are used by the ummah (Muslim community) is looking for the format of an ideal Islamic leadership system. The Qur'an also presents the principles of leadership that should be owned by leaders in carrying out their leadership (Istikomah \& Haryanto, 2021). 
The principles of educational leadership generally studied are those of integrative and cooperative capacity, rationality, and objectivity, adaptability and flexibility, delegation, pragmatism, and exemplary. While the principles of educational leadership in the perspective of the Qur'an are those of ta'wid, deliberation, 'adalah, hurryiyah, trust, amar ma'ruf nahi munkar, and uswah hasanah. From the two principles, educational leadership includes education for a leader that is appropriate with the characters of the Qur'an: namely, a leader who (10) is tolerant, (2) likes to confabulate, (3) determines the laws justly, (4) gives freedom, (5) may be trusted, (6) always does good things, and (7) gives good exemplary (Ahmad \& Ogunsola, 2011).

The objective of this present research was to show the basis of the principles of educational leadership in general and in the perspective of The Qur'an. Dealing with the matter, the scope of this research is twofold, the first is to describe Islamic education and the second is to outline the principles of educational leadership from the perspective of the Qur'an.

\section{B. Literature Review}

\section{Leadership}

Leadership is from the root word "lead" with the meaning of "to lead", namely: 1) to hold hand while walking, 2 ) to show a road; chair, head; 3 ) to train (educate, teach, and the like). "Leader" means someone who leads, (also figurative meanings like a guide, teacher, leader, troop head, and so on). "Leadership" means something about a leader, the way to lead (Poerwodarminto, 2014). Leadership is the capability of persuading others to work together direction as a team to accomplish certain designated objectives (Rivai \& Arifin, 2013).

Northouse (2013:2) summarizes the definition of leadership evolutes (changes) through times:

- In 1900-1929, leadership was defined as the ability that emphasizes the leader's desire to the one led and encourages obedience, appreciation, loyalty, and cooperation (Moore, 1927:124).

- In the 1930s, leadership was defined as an interaction of special personality characteristics owned by someone and those possessed by the group. It should be noted that attitudes and activities made by many people are influenced by one person, and the followers also affect their leader.

- In 1940a, leadership was defined as individual attitudes when directing group activities (Hemphill, 1949). At the same time, leadership with persuasion was distinguished from "attitudes and methods in supervising people" or leadership with coercion (Copeland, 1949).

- In the 1950s, three themes dominated the definition of leadership in this decade: (i) The continuity of the group theories, shaping leadership as what is done by a leader in a group; (ii) Leadership as the relation that develops the common goals, and defining leadership based on the lead actor, and (iii) Effectiveness, where leadership was defined by the ability to influence all group effectiveness. 
Sa'dullah Assai'di et al.

- In the 1960s, the main definition of leadership was attitudes that influence people to reach the common goals as underlined by Seeman (1960: 53) who describes leadership as "an act done by people who affect others at the same direction".

- In the 1970s, leadership was viewed as "shaping and defending a group or an organization to reach the group or organizational goals" (Rost, 1991:59). But Burn's (1978:425) definition was the most important concept of leadership. Leadership is a process of a reciprocal mobilization conducted by those with certain motif and values, various economic and political sources, and other resources in the context of competition and conflict to realize the goals autonomously or collectively by possessed a leader or his followers.

- In 1980s, in the decade, leadership was divided into some themes: (1) Do as the leader asks. The definition of leadership in general still conveyed a message that leadership makes the followers do what is intended by the superior; (2) Influence is the effort to differentiate leadership and management, the academy states that leadership is non-coercive influence; (3) Characteristic. It was triggered by a bestselling book In Search Excellence (Peters \& Waterman, 1982). As a result, many people's understanding of leadership is based on the orientation of characteristics. (40 Transformation. Burn (1978) was appreciated because of the movement that defined leadership as transformational progress.

\section{Educational Leadership}

Educational leadership is an ability for and a process of influencing, coordinating, and moving others in terms of the development of the educational science from the implementation of education and instruction so that the activities conducted may be more efficient and effective in reaching the instructional and educational goals (Subhan, 2017; Rozak, 2014).

Leadership is a determinant of the effectiveness and efficiency of an organization. Therefore, the quality of a leader determines the success of his institution or organization. Because, a successful leader is able to manage his organization, may influence others constructively, and show a correct way of what should be done together (Beekun \& Badawi, 1999). Without leadership, an organization is merely a mess of people, leadership is an ability to urge others to reach goals that have been determined in a full of passion. Leadership changes potency into reality. It is the last action that brings the success of all potency existing in an organization and its people (Sutisna, 1989:193).

Imam Al-Ghazali thought that a human is a social creature. Therefore, he cannot live alone. Moreover, he saw that there are two factors that cause why humans become social creatures, first, they need offspring for the survival of human beings. This can be done through the association among men, women, and families. Second, they need to help provide food, clothes, and education for children (it needs cooperation and to help each other among humans) (AbOuji, 1999). 


\section{General Principles of Educational Leadership}

A principle is an essence (a truth that becomes the basic point to think, act, and the like). A principle is a fundamental statement or a general or an individual truth adopted by someone/a group of people as guidelines to think and to act. Terminologically, a principle $(a ;-a s l)$ in Arabic means something that is used as the basis for a building, or the basic foundation where above it, something either material or immaterial is established (Ali \& Muhdlor, 1996). It may be concluded that a principle is something that has become the basic guidelines considered to be correct to determine the next actions.

The word "general" linguistically is about all or the whole (is not specific, special) things in a comprehensive way, and it does not deal with something special (certain), for a lot of people, for anyone. The word "general" is still wide in terms of its scope. What is meant by a general principle is the basic guidelines that become a basis to determine a policy where its scope is still wide. In order to carry out the mandate in education, the principles of general leadership that apply should be understood and conducted, namely:

\section{a. Integrative Capacity}

The principle of integrative capacity is extremely important for a leader because it is the administrative and organizational capacity that may be moved as a total system towards the attainment of the determined goals. Integrity is a consistent act, either internal or external values. A high integrity leader is the same either in or out of internal values, in what meaning exists in oneself or in the appearance in the surface appearance. Therefore, a leader should have trust from his followers so that he should show his integrity. He should be honest in transactions, his reaction can be predicted, his emotions

are well controlled, and he is not easy to be angry. Moreover, a high-integrity leader will be more easily approached by his followers (Damanhuri, 2018).

By this principle, educational leaders should be able to unite the vision, missions, and goals to reach all civitas of education so that in doing their functions, they may carry them out in line with the moves and the steps of the launched programs.

\section{b. Cooperative}

In the process of his leadership, a principal should accentuate cooperation with the people he leads, because, in this cooperative principle, a participant should be improved into dynamic cooperation. Where each member, besides being responsible for his own task, should also have an interest in the problem involving the success of other members' jobs. Due to such feelings and awareness, they might help and cooperate with one another for each effort to solve problems arising in their institution that might hinder the success in reaching the goal of the institution.

As an educational leader, a principal should also try to arouse and enrich awareness for each member to make him/her own responsibility and then actively think and solve problems dealing with the planning, educational programs, and learning. Because the success in obtaining proper decisions or problem-solving in an educational institution satisfactorily may merely be achieved through efforts the leader makes by including his 


\section{Sa'dullah Assai'di et al.}

members (Hutagaol et al., 2018).

\section{c. Rationality and Objectivity}

A leader will not succeed if he drives his organization emotionally. It means that if emotions rule a leader's way of thinking, his rationality and objectivity will reduce and this, in turn, may result in improper decision makings. This rational leadership is marked by a figure's performance based on his ability and competence. The higher the managerial position one has, the more demands for him to prove one ability to think will be. This thought will result in impacts not only in the organization but also in the organizational relations with the concerned parties out of the organization.

In viewing or deciding a problem, a leader should be open, meaning that he should consider all aspects and their chronology. Openness means being able to listen to new ideas, even the ideas are inappropriate with ordinary thoughts. Openness in leadership will create the feels of respect between the leader and his followers and establish a good team with new ideas to realize his vision (Bunza \& Abdulkarim, 2021). It means that a leader should prioritize justice in considering a problem comprehensively and one-sidedly. As a result, those who are led will feel being protected with the clarity of their status, where one who does mistakes will get punishment and those with good achievement will obtain rewards (Fitriyah \& Suliyadi, 2018).

\section{d. Adaptability and Flexibility}

If there is an opinion that says that the only constant thing in the world changes, rigid and stiff attitudes will be harmful to someone in playing his role as a leader. From such flexibility, an organization will guarantee work relations and work procedures which are in accordance with the reality and new problems that are emerging and changing. The change is inseparable from various human relations among staff members. Therefore, the principle of flexibility is a vital factor in an organization.

Adaptive means being smart in adapting oneself to changes. An adaptive leader means leadership that easily adjusts oneself to new changes and conditions. Changes always establish new views, and the new views will affect various ongoing events. If a leader does not own a good personality to answer the new views, he will face problems to deal with the changes. An effective leader is someone who can flexibly apply a leadership style appropriate to the development and the condition of his staff (Juhji et al., 2020).

e. Delegation

As an educational leader, a principal should realize that his ability as a human is limited so that he needs to delegate his power, authority, and responsibilities to the members of his staff according to their own ability, with the intention that the working process as a whole may run smoothly, effectively and efficiently. Leadership coaching through training in the form of delegation is one of the practical ways for the interest in improving the quality of education in the future. It means that actually, the success of leadership is dependent upon one's ability in delegating tasks and responsibilities to his 
subordinates effectively.

This delegation should be implemented since it is impossible for a group/organization to advance by itself. As a result, deliberation and consultation play important roles, especially for those who receive the delegation, they must always be oriented into general policies made by the leader. Participation in leadership might be merely realized if the leader develops a communication that facilitates the exchanges of thoughts, ideas, and points of view in solving problems where they may be used by the leader in making his decisions. A leader should be able to trust his colleagues in doing the tasks given to them to do as many activities as possible. But, all of the implementations should be measurable and be morally and constitutionally accountable (Hermawan, 2019).

\section{f. Pragmatism}

An educational leader should be able to make accurate decisions in line with his ability and available sources. It is one of the characteristics of a good leader. Pragmatic leadership is a leadership concept required to make decisions timely, quickly, and effectively, but they do not break the principles. Pragmatism means a concentration on the facts instead of emotions or ideals. It means that a leader should behave realistically on the basis of a plan, and he is willing to do steps by steps to make production actions from real situations.

A leader in deciding something should also be able to realize and translate it into an instruction/an order. Then the order will be meaningless if it is not executed. In carrying out an order, a leader should be able to direct the goal to the people he leads towards what will be reached. In essence, leadership is a leader's ability in driving others to do the tasks coming from decisions that have been determined (Hermawan, 2019).

\section{g. Exemplary}

In leading an educational institution, an education leader should be able to become a good example. A leader can not only command and evaluate his subordinates' performance but should also give a good working example. A leader should spend the time and energy required to complete the tasks under his responsibility. He should inspire dedication by giving examples, do anything to finish his tasks, and being responsible towards the vision. By giving good examples, a leader may inspire his subordinates that a job should be seriously done (Rukiyah et al., 2021).

In the Regulation of the Ministry of Education No. 13 the Year 2007 regarding the Standard of the Principal (School/Madrasah), it is stated the qualification of a person to be able to become the Principal (School/Madrasah) either generally or specifically. It is also mentioned, a principal should possess competencies to fulfill, namely: (1) Personality competence, namely, he has noble characters, integrity, open attitude, talents, and interest as a leader; (2) Managerial competence: he may make plans, develop and lead schools/madrasah, manage finances and service units, make use of technology advancement and do monitoring; (3) Entrepreneurship competence: he may create innovations for the development of the school/madrasah, work hard, never give up, and 
possess entrepreneurial instincts; (4) Supervisory competence: he may plan programs and carry out supervision and follow up educational supervision, and (5) Social competence: he may cooperate with others, participate in social activities, and have sensitivity to others.

A leader must expect his planned programs to succeed as intended. According to Gerungan (2006), there are three requirements that should be met to be able to become a successful leader having three visions: (1) Visual social acuity. Visual social acuity here is an ability to see and understand symptoms emerging in society or daily life, especially those dealing with feelings, behaviors, desires, and needs of fellow members of the organization. They may be basic or complementary needs; (2) Abstract thinking skills. Abstract thinking skills are that a leader should have a smart brain since it is required by a leader to see, interpret, and evaluate activities implemented by the members of his organization, and (3) Emotional balance. Someone with unstable emotions will not be able to lead others, since he cannot calm himself down. A leader should be able to create calm and safe feelings for those he leads. This is possible if he himself behaves calmly and safely since he has emotional balance.

\section{Research Methodology}

The method adopted in this research was the maudu'i (thematic hermeneutics) exegesis by sorting out the verses of the Qur'an that are related to one subject and one goal. Using a detailed examination and after annexing each other, this research did not consider how the variety is in words and types of places. Moreover, this integrated study also took into account the beginning and the end of the verses, the uses of asbabun nuzul, and the Sunnah An-Nabawiyah, and also opinions from salaf ulema concerning the subjects (Aziz, t.t: 21).

In its division, there are three types of Tafsir Maudu'l. 1. Maudu'i exegesis from the terms of The Qur'an. 2. Maudu'i exegesis from the themes of the Qur'an, and 3. Maudu'i from the surrahs of the Qur'an (Aziz, t.t.: 21). In the context of this research, the authors chose the second type namely the Maudi'i exegesis from the Themes of the Qur'an, since using this exegesis, the researchers could choose the themes of The Qur'an in line with the research subjects (Yamani, 2015).

The steps in the Maudu'i exegesis according to Ahmad Sayyid Al-Kumiy (1960) cited by Shihab (1996) are as follows:

1) Choosing or determining the problems in the verses of the Qur'an that would be studied with the mauddu'i (thematic) fashion.

2) Collecting all the verses of The Qura'in existing in all surrahs of The Qur'an dealing with and talking about the themes to study either the makkiyyat or madaniyyat surrahs.

3) Determining the orders of the verses collected in accordance with the times of the revelations and showing the causes of the revelations if possible (meaning, if the verses were revealed because of certain causes).

4) Explaining the relevance (munasabah) among the verses in each surrah and the relation among the verses and the verses before and after times in each surrah (it is 
recommended to review the tahlily exegesis).

5) Arranging the discussion of the themes using an appropriate, systematic, perfect, and complete framework covering all aspects of the themes.

6) Presenting the Prophet's hadiths about the theme and doing takhjrih and explaining the levels of the hadiths to more convince others who study the theme. 5) The stories (atar) from the companions and tabi'in are also presented.

7) Referring to the Arabic khalams (expressions) and their verses in explaining the pronunciations in the verses about themes studied and explaining their meanings.

8) Studying the verses with maudu'i method comprehensively by compiling verses that contain similar meanings, compromising the concept between which one is 'am and khas, between what is mutlaq and muqayyad, synchronizing the verses which seem explicitly contradictory, explaining the nasikh and mansukh verses, so that all of the verses meet in one estuary without any differences and contradictions or actions of coercing to one verse in terms of meanings which are actually improper.

The data sources were the primary and secondary data. The primary data was Book on Exegesis, consisting of (i) Tafsir Qur 'anil Azim, authored by Ibnu Katsir; (ii) Ahkamul Qur'an, written by Ibnu 'Arabi; (iii) Tafsir Ad-Durru al Mantsur, karya Abdu Ar-Rahman bin Al Kamal As- Suyuti, and (iv) Tafsir modern Al-Qur'an dan Tafsirnya, Departemen Agama $\mathrm{Rl}$, 2009. In addition, the secondary data are books on ulumul Qur'an and asbab al-nuzul AlQur'an, that include: (1) Al Itqan fi 'Ulumi Al-Qur'an, written by Abdu Ar-Rahman bin Al Kamal As-Suyuti; (2) Al Ikhtilaf fi at-Tafsir, Haqiqatuhu wa Asbabuhu, (3) Some books on hadith: Jami' al hadis, karya Abdu Ar-Rahman bin Al Kamal As-Suyuti, (4) Al Ahkamu AsSultoniyah, karya Abi Al-H|asan 'Ali bin Muhlammad bin Habib Al-Bas|hri Al Mawardi; (5) Books, magazines, journals, the Internet and other data related to the themes. Moreover, to complete this study, the authors also took a salaf book as the source to facilitate the writing of this article. Moreover, the authors also used Maktabah Syamilah program and the Digital Qur'an.

Concerning the method of the data collection, library research or pure library research was adopted (Nasution, 2006; Hadi, 1998:9). On the basis of the study on the principles of leadership in the Qur'an, in general, a research method of the Our'an namely the thematic and exegesis methods were adopted. A thematic method is an effort to study hadiths based on the themes in question, using an approach to various disciplines. The first step was done by collecting the verses of the Qur'an in accordance with the same themes namely the principles of leadership. In the process of compiling the verses of the Qur'an, the authors used the Maktabah Syamilah program using the bahtsu fi nusus (http://maktabahsyamilah.com/) method.

Therefore, using the maudu'i method, the authors tried to look for something intended and the nature of a problem in an easy way without having to struggle to solve a difficulty in understanding the exegesis. Still, another side is that by adopting the maudu'i method, the author could know and understand the explanation of the Qur'an to answer 


\section{Sa'dullah Assai'di et al.}

the themes intended as a whole (Iqbal, 2010; Al-Farmawiy, 1977).

\section{Results and Discussion}

\section{Principles of Educational Leadership in the Perspective of the Qur'an}

Leadership is the embodiment of the mandate given by Allah SWT and it has good (hasanah) rules. It is stated by the Prophet's hadith that in humans, a leader is implanted, therefore, there is a leadership spirit that enables one person to influence another. As a result, rules in interactions in life are needed. Educational leadership in the perspective of Alquran includes:

\section{a. Ta'wid}

In God's words in the Surrah Ali Imron verse 64, it is mentioned an invitation to the scribes to do the same sentence among them and the Muslims namely to worship Allah, and not to associate anything with Allah, and not to make a God other than Allah. From various principles of leadership the authors have described above, it is shown that in the life order, the principles will be pursued to protect human rights, namely, basic rights attached in humans possessed from birth to death (Al-Bahiy, t.t.).

Human is a creature that is highly glorified by Allah SWT to whom he has given rights and privileges. God's revelation:

$$
\text { ولتداةلأ آوحمب ا خلمفي ? و؟بئروررئثم غ الج ات وظاهم >جرمئن }
$$

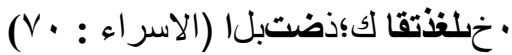

That Means "And We have honored the Children of Adam. We carried them in the land and the sea, and We have given them as sustenance of the permissible things, and We have made them excel by an appropriate excellence over most of those whom We have created.". (OS. Al Isra': 70) (Abdillah, t.t.:8).

Humans born into the world have been given rights by Allah SWT where the rights should be respected. It means that before Allah SWT, all humans are equal. They are created by Allah. Their differences in races, religion, ethnic groups, and language show the power of Allah SWT. God's revelation:

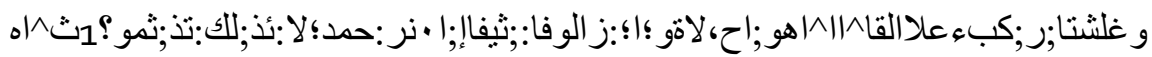

(1) 1 - $111: 0)$

It means that "And if your Lord had willed, He would certainly have made mankind a single nation. Yet they shall continue to differ. Except whom your Lord has given mercy, and for that He created them. But the word of your Lord is to be fulfilled that,

"I will surely fill Hell with jinn and men all together." (OS. Hud:118-119). 
In the social order, Allah SWT makes rules (tasyri') through the revelation to His prophets so that human life goes in line with the rules, namely to respect one another and not to fight one another.

According to the Usul Fiqh umela, Allah sent down Islamic sharia with some goals namely:

1) Dlaruriyat/1 ضروريات the (main): important thing to meet for the continuation of human life. If it is not fulfilled, destructions, riots, and chaos of human life will occur.

2) Hajiyat/الحأجيك (secondary ): anything needed by humans to obtain spaciousness and convenience in life on earth. If it is not satisfied, humans will have troubles and narrowness.

3) Tahsinat/الات (tertiary ): complementary things consisting of good habits and akhlaq (Ali, t.t.:130).

More clearly, Az-Zuhaili describes the main goals (اسدرن) consisting of protection to religion, spirit, reason, offspring, and possession (Azzulahili, t.t.:93).

It is told that the Badr War occurred, the news of the victory of Roman over the Persian was heard. The Romans at that time believed in Christian while the Persians were atheists. Before that time, the polytheists satirized the Prophet and the Muslims since they were happier if the Persians, who accidentally were atheists, defeated the Romans who in this case believed in heavenly religion (Arabi, 1994: 274).

\section{b. Deliberation}

Allah suggests the Prophet and his ummah do deliberation in organizational and social life. It is stated in surrah Ali-Imran verse 159: On the basis of the verse in The Qur'an, the order to do deliberation is preceded by the attitude of the people who will do liberation: being gentle, giving forgiving, asking for forgiveness for the mistakes of others. The attitudes are greatly important to support the success in deliberation (Department Agama RI, 2007).

From the wording of this verse, accompanied with the order to forgive and the like, it is as if that this verse says: actually your attitude, $\mathrm{O}$, Muhammad is a greatly noble one, you are not insistent, and are not rough hearted, you are forgiving, and you are willing to listen to suggestions from others. All of them are caused by the blessing given by Allah who has educated you so that all of the factors that may influence your personality are removed by Allah.

His revelation says: "If you behaved rudely..." means that you Muhammad are not stubborn It can be understood that the word law which translated into ' if'". This word is used to describe something conditional, but the condition cannot be realized. Therefore, when this verse states that if you were rude again, you were stubborn, certainly they would keep away from your surroundings so that being rude and stubborn does not exist, therefore, they would keep away from your surroundings will never happen. 


\section{Sa'dullah Assai'di et al.}

1) The Obligation to Deliberate

The obligation to deliberate has been stated by Allah SWT in The Qur'an in the form of an order. Al-Fakhr Ar-Razi stated: the order explicitly is obligatory. Therefore, in His revelation it is said: And deliberate with them, it means an obligatory. But, many experts said that deliberation is a sunnah as said by Al Hifni (t.t.: 130).

Deliberation is obligatory for the government or those possessing responsibility among the people or family. This can be understood from the sentence شاورئم في الأمر (deliberate with them in this matter). This obligation is not merely limited to the government, it also includes each group until the smallest unit like between a husband and a wife (Ridwan, 2007: 22).

\section{2) The Scope of Deliberation}

The verses showing deliberations have not had a scope. As a result, the ulemma have different views about this. Ibnu Arabi said that the deliberation is merely done for war problems since it has been outlined by Allah or prophets (Ibnu Arabi, t.t.:129). According to Al-Qurthubi, deliberation is done for war problems also other problems using the ijtihad method (Al-Qurthubi, t.t.:250).

\section{3) The procedure of deliberation}

Dealing with the procedures or the requirements to follow the procedures, no nash in The Qur'an and sunnahs explains about them. If there is no nash that requires the determination of the number of the deliberative council members and the way to bring them. The procedures of deliberation practiced by the Prophet are greatly various, among others: (1) Sometimes when someone gave a consideration to him, then he knew that the opinion was correct, then he implemented it. It is in line with an opinion presented by alHubab ibn al-Mundzir about the choice of a strategic place for the Badr war and the idea proposed by Salman al-Farisi about the defense trench digging in the Khandaq war; (2) Sometimes, the Prophet deliberated with two or three persons only, especially with Abu Bakar and "Umar"; (3) Occasionally, the Prophet also deliberated with all mass through representatives, such as that occurred after the Hunain war to discuss the spoils of war and the request for help through Hawazin messengers (Olyas, 2007:223).

\section{4) 'Adalah}

Justice is the building foundation that must be erected, it is a pillar for the community life even the universe. Allah orders to decide the law justly among humans, so that this nash is absolute that means that it includes a holistic justice "among all humans", instead of justice among the Muslims or to the scribes. Muslims should uphold this justice in deciding the law among humans if they decide the law in their dealings with a justice that has never been known by humans except under the hands of Islam, except in the law of the Muslims, except in the Islamic leadership periods to humans only. For someone losing justice before and after this leadership, he would not be able to feel it that he was noble, as that given to humans since they are merely humans, not because of other 
characteristics as the addition from their main identity possessed by all humans (Faiz, 2009).

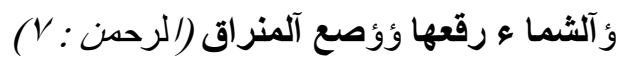

It means that "And the heaven He raised and imposed the balance". (OS. ArRahman: 7)14

$$
\text { سحد و آدعوه }
$$

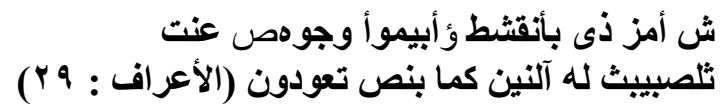

It means that "Say:

"My Lord has commanded you to act injustice". and that: "You should set upright your faces in every place of worship to prayers". And call on Him rendering the Religion peculiar to Him only. As He created you, so shall you also return (to Him)."(OS. Al A'raaf: 29).

\section{5) Hurriyah}

According to Ridhwan (2007:35), legislation that becomes the basic law in Islam has four main principles namely equality, freedom, justice, and social needs. Freedom or independence is human rights covering various dimensions and activities. In this matter, Allah SWT gives freedom to humans to express their actions. Allah says:

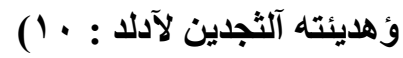

It means that "And We deliver him to ways (the Way of Hidayet and the way of Misguidance)". (OS. Al Balad: IO)

Humans are provided minds that may be used to think and to do tadabbur of the signs of the greatness of Allah SWT. Therefore, humans are given the freedom to choose the way that will direct them to walk towards eternal happiness, or he chooses the wrong way that will lead them to the road of destruction and disbelief.

$$
\text { ين ويل صداحا فبئنسوئ ومن )سا · ع فع و ·ما ربك بغئر لاع?يد (نصلات : } 7 \text { ؛ ؛ ) }
$$

It means that "Whoever works righteousness benefits his own soul; whoever works evil, it is against his own soul: nor is thy Lord ever unjust (in the least) to His Servants." (QS. Fushilat: 46).

\section{6) Amanah}

The word "amanat" that becomes the subject above is the plural form of the word "amanah". Linguistically, amanat is the masdar form of the word - or by following the wazan/structure اسل becomes amanah that means sincere or can be trusted. In another sense, amanat is something that is trustedd (deposited) to another person, message, or order (from above), trust (maybe trusted).

According to Muhammad Hasbi Ash-Shiddieqy, amanat is something that is complete and plural, covering a servant (umah)'s amanat to his God, namely doing the 


\section{Sa'dullah Assai'di et al.}

order and avoiding the ban, like completing the ummah's amanat to fellow ummah. For example, handing over the deposit, repaying a loan, maintaining all rights, behaving well to the wife, relatives, human, or the government's apparatus (Ash-Shiddieqy, 1994).

\section{7) Amar Ma'ruf Nahi Munkar}

Amar ma'ruf nahi munkar is included in the basics of Islam determined using binding regulations, because in them, God's religion and refusing others will be enforced. $n$. God's revelation:

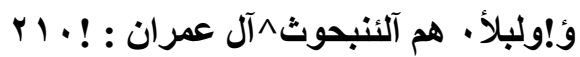

It means that "Let there arise out of you a band of people inviting to all that is good, enjoining what is right, and forbidding what is wrong: They are the ones to attain felicity.." (OS. Ali Imron: 104).

In practice, the Prophet regulates the level in encountering evils where he said:

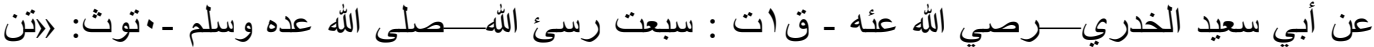

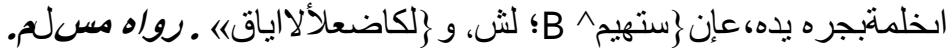
meaning: From Abi Sa'id al Khudry RA, it is said: "I heard the Prophet saw spoke: "Those see an evil deed should change it with their own hands, if they cannot do that, they do it with his speech, if they can not do that, they can change with their hearts. And that's the weakest of faith". (HR. Muslim).

In this hadith, it is explained the way to change evils by closing, throwing away, or just inkar fi qalbi. If you can't stand it, when you should do war, it is under the area of the government.

8) Uswah Hasanah

God's revelation:

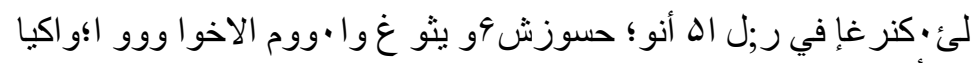

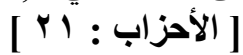

meaning: "There has certainly been for you in the Messenger of Allah an excellent pattern for anyone whose hope is in Allah and the Last Day and [who] remembers Allah often." (QS. Al Ahzab: 21).

The verse describes the Prophet's exemplary in all areas of life. Then Allah SWT creates the indicators of a Muslim's obedience to the Prophet as his love to Allah SWT. God reveals:

$$
\text { ض ن كغ تحيون آد فأتجثويى تخد آس وشذ لو ذيوع ؤآس غغوز رحغ [ ال عمران : Irاس }
$$

Meaning: "Say, [O Muhammad], "If you should love Allah, then follow me, [so] Allah will love you and forgive you your sins. And Allah is

Forgiving and Merciful". (QS. Ali Imran : 31).

According to Ibnu Qoyyim, following the trace made by the Prophet may be used as 
the proof of love to Allah and His prophet. Then the absence of mahabbah when the absence of mutaba'ah happens, the absence of mahabbah to Allah SWT shows the absence of mahabbah to His Prophet. It is shown that following the trace of the Prophet means loving to Allah and His Prophet and obeying His order. It is not enough to worship only so that a servant loves Allah and His Prophet more than to others. Therefore, there is nothing to love more except Allah and His Prophet. If this happens, the deep is included into shirk that is not pardoned by Allah SWT (Al-Maraghi, 2006).

This principle was proposed by Ki Hadjar Dewantara with his trilogy, one of which is "Ing Ngarso Sung Tuladha" meaning that The leader at the front should give an example. Sung is from the word asung where in Javanese it means to give. In the sentence Ki Hajar Dewantara gives a message that the word sung is meant to become, because between giving and becoming have different meanings

The first principle given by Ki Hajar Dewantara describes a situation where a leader is not just someone walking in front but he should become the example for those following him. The phrase In Ngarsa cannot stand alone if it does not have an explanatory sentence behind it. It means that someone in front if he has not given an example, does not deserve the title of leader. If we know leadership from the people in history, we can see how the leader's deed become inspirations for those he leads.

\section{Educational Leadership in the General Perspective and the Qur'an}

From the descriptions about the general principles in leadership and the principles of leadership from the verses of the Qur'an supported by opinions given by the ulemma and experts in the principles and the explanations, it can become a unity of principles of educational leadership on the basis of The Qur'an covering the education of morals for someone who will become a leader in accordance with the morals of the Qur'an.

\section{a. Being Tolerant}

An educational leader should respect differences in the citizens he leads, either individual differences like religion or races, or community ones such as parties and so on. If an educational may collaborate all differences it will create strengths for the educational institution. The authors took this principle from the general leadership principle namely the integrative capacity and the leadership principle in the Qur'an namely $t a^{\prime}$ wid.

\section{b. Preferring to Do Deliberation}

A leader should always do deliberation when every time he takes a stance and a decision dealing with the interest of many people. All problems are solved through deliberation because through this was, opinions proposed by the members may be accommodated and this may result in a wise decision that may be accepted by all parties. Someone who deliberates, especially the one in an upper position, will first accept criticism and inputs as the consideration in making decisions. This principle is the conclusion of the general principle of cooperative leadership and the leadership principle in The Qur'an, namely deliberation. 
Sa'dullah Assai'di et al.

c. Being Just

An educational leader should be firm and just in doing his task as a leader to enable the educational institution to produce just rules regardless of skill color, social and economic status, and so on. The authors took this principle from the general principles of rationality and objectivity leadership and the leadership principle in the Qur'an namely 'adalah.

\section{d. Giving Freedom}

An educational leader should give freedom as much as possible to the citizens he leads, either the freedom in giving opinions, making innovations, and creations to advance the world of education. The freedom given should the one that is not absolute but the freedom that is responsible. The authors wrote this principle from the conclusion of the understanding of the general principle of adaptability, flexibility, and objectivity leadership and the principle of leadership in the Qur'an namely hurriyah.

\section{e. Being Able to Be Trusted}

If it is related to the world of education, amanah here is a principle of accountability of a leader to the administrative $c$ function and the (supervisory) control to the educational staff or members to realize the vision-mission that will be implemented and to embody the educational goal itself. This principle was concluded by the Authors from the general principle of delegation and principle leadership in the Qur'an namely amanah.

\section{f. Always Doing Something Good}

To create a balance in implementing the teaching-learning activities, an educational leader should have the courage to convey good and correct things and should also be brave to admonish the citizens he leads if they break either moral or religious norms. This principle was taken by the authors from their understanding of the general principle of pragmatic and principle leadership in the Qur'an namely amar ma'ruf nahi munkar.

\section{g. Giving Good Exemplary}

An educational leader does not only give orders but also gives good concrete examples to his subordinates in terms of attitudes and behaviors so that they will be imitated. This principle was taken by the author from the general principle of exemplary and principle leadership in the Qur'an namely 'uswah hasanah. The educational leadership principles presented above are not intended to look for an ideal educational leader. It is more than that, namely the principles will be more meaningful if they are applied in social life, in national life especially in the world of education with the hope that the goal of the educational leadership in the Qur'an may be realized.

\section{Conclusion}

Leadership in the perspective of Islam is not merely a social contract between the leader and his community. Leadership is a trust from Allah SWT that should be maintained 
and responsible. Leadership bears power and authority which merely enable to do the responsibility in serving the people one leads as the realization of the caliph on earth. Leadership education is very vital to manage an educational institution with the intention that the vision, missions, and goals of the institution can be attained in accordance with the programs that have been determined together.

The principles of educational leadership in the Perspective of the Qur'an", are: a) Ta'wid, a leader should have the same view and tolerance in life, b) Deliberation, a leader should accept inputs and criticism in making decisions. C) 'Adalah, he should be just in deciding a problem. D) Hurriyah, has freedom as much as possible but he should be responsible. E) Amanah, he should be trusted in doing leadership tasks, f) Amar ma'ruf nahi munkar, he should be firm in enforcing rules, convey goodness, and crackdown crimes. And g) uswatun hasanah, he should be a good example to those he leads. From the general leadership principles, if they collaborate with the leadership principles in The Qur'an, they will produce the following leadership principles: being tolerant, preferring to do deliberation, being just, giving freedom, being able to be trusted, always doing something good, and giving good exemplary.

\section{BIBLIOGRAPHY}

Abdillah, Yusuf al Hathi. (t.t.) Al Inayah bil Qur 'anil Karim fil Ahdi an-Nabawy asy- Syarif, in Maktabah Syamilah, $V_{3} .8$

Ahmad, K., \& Ogunsola, O. K. (2011). An Empirical Assessment of Islamic Leadership Principles. International Journal of Commerce and Management, 21(3), 291-318. https://doi.org/10.1108/10569211111165325

AbUoji. (1999). Politik Kenegaraan: Pemikiran Politik Al-Ghazali karya Ibnu Taimiyah. Bina Ilmu

Ahmad, T. S. (2015). Life Long Education Sebagai Jalan Menuju Insan Kamil. An-Nahdlah, 2(1), 19-42.

Al-Farmawiy, 'Abdul Hay. (1977). Al-Bidayah fi Tafsir Al-Mawdhu'iy. Al-Hadharah Al'Arabiyah, cetakan II

Ali, At.tabik \&Ahmad Zuhdi Muhdlor. (1996). Kamus Kontemporer, Arab-Indonesia. Multi Karya Grafika

Al-Maraghi, Ahmad Musthofa. (2006). Tafsir Al-Maraghi, Darul Kutub Al- 'llmiyah

Al-Qurthubi. (t.t.) Tafsir Al-Qurthubi, juz 4, hal. 250, dalam Maktabah Syamilah V.3.8

Al-Ayubi, S. (2011). Metodologi Penafsiran Al-Qur'an. Fikroh: Jurnal Pemikiran dan Pendidikan Islam, 4(2), 95-104.

Arabi, Ibnu. (1994). Al-Futuhat Al-Makkiyah. Dar Al-Fikr

Arabi, Ibnu. (t.t.) Ahkamu Al-Qur'an , juz 2, in Maktabah Syamilah V.3.8, t.t).

Aziz, Abdul Mughni Abdul. (t.t.) Al-Tijarah fi Al-Qur'an ul Karim, Juz 1 dalam Maktabah Syamilah, V. 3.8

Azzulahili, Wahbah. (t.t.). Fiqhul Islamy. in Maktabah Syamilah, V. 3.8

Beekun, R. I., \& Badawi, J. A. (1999). Leadership: an Islamic perspective. Amana.

Dinamika Ilmu, Volume 21(2), 2021 
Sa'dullah Assai'di et al.

Bunza, Umar, Mukhtar \& Abdulkarim, Lawal. (2021). Scientific Education among Muslims in Northern Nigeria: The Influence of Middle Eastern and Midetaraion Scholarship. Dinamika Ilmu, 21(1): 1-6. DOI: 10.21093/i/v21i1.2554.

Damanhuri, M. (2018). Kepemimpinan Pendidikan dalam Tinjauan Ilmu Shorof. Ta'dibi : Jurnal Prodi Manajemen Pendidikan Islam, VI(2), 63-91.

Danim, Sudarwan. (2010). Kepemimpinan Pendidikan, Kepemimpinan Jenius (IO+EQ), Etika, Perilaku Motivasional, dan Mitos. Alfabeta

Faiz, P. M. (2009). Teori Keadilan John Rawls. Jurnal Konstitusi, 6(1).

Fitriyah, N. A., \& Suliyadi, A. (2018). Membangun Kompetensi Pemimpin dalam Mengelola Organisasi Publik: Strategi dan Aplikasi. MADANI Jurnal Politik dan Sosial Kemasyarakatan, 10(1), 79-91.

Gerungan, W.A. (2006). Psikologi Sosial. Eresco

Hermawan, E. (2019). Pengaruh Kompetensi, Pendelegasian Wewenang dan Kepuasan Kerja Terhadap Kinerja. Maneggio: Jurnal Ilmiah Magister Manajemen, 2(2), 148-159. https://doi.org/10.30596/maneggio.v2i2.2235

Hutagaol, K., Saija, L. M., \& Simanjuntak, D. C. (2018). Model Pembelajaran Kooperatif Ing Ngarso Sung Tulodho, JURNAL PADEGOGIK, 1(2)

Ilyas, R. (2016). Manusia sebagai Khalifah dalam Pespektif Islam. Mawa'izh, 1(1), 169-195. https://jurnal.Ip2msasbabel.ac.id/index.php/maw/article/view/610

Ilyas, Yunahar. (2007). Kuliah Akhlaq. Lembaga Pengkajian dan Pengamalan Islam Iqbal, M. (2010). Metode Penafsiran al-Qur'an M. Quraish Shihab. Tsaqafah, 6(2), 248-270. Shihah, M. Quraish. (2018). Tafsir Alquran tentang Kepemimpinan. Tsaqafah, 6(2), 248. https://doi.org/10.21111/tsaqafah.v6i2.120

Istikomah, I., \& Haryanto, B. (2021). Manajemen dan Kepemimpinan Pendidikan Islam. Nizamia Learning Center.

Jashaash Al Hifni, Ahkamu Al-Qur 'an , juz 2, al. 330, Maktabah Syamilah, V. 3.8

Juhji, J., Syafe'i, Z., \& Gunawan, A. (2020). Kepemimpinan: Sebuah Kajian Literatur. AtTarbiyat: Jurnal Pendidikan Islam, 3(2), 172-186.

Muhammad Al-Bahiy. (2013), Tafsir Al-Qur'an Al-Karim, Mahmud Syaltut, Dar Al-Qalam, Mesir, cet. II

Nasution, M. K. M. (2006). Metodologi Riset. PT Bumi Aksara (Issue June).

Northhouse, Peter G. (2013). Kepemimpinan: Teori dan Praktik, Edisi 6

Poerwodarminto. (2014). Kamus Besar Bahasa Indonesia. PT Gramedia

Ridwan. (2007). Fiqih Politik: Gagasan, Harapan, dan Kenyataan. FH UII Press

Rivai, H. Veithzal \& Arifin, Arviyan. (2013). Islamic Leadership. Bumi Aksara, Cet. II

Rost, J.C. (1991). Leadership for the Twenty-First Century. Praeger.

Rozak, Hefniy. (2014) Kepemimpinan Pendidikan dalam Al-Qur'an, Tinjauan Sakralitas, Profanitas dan Gabungan. Teras

Rukiyah, I., Kadir, M., \& Ulfah, Z. (2021). Challenges of Managerial Functions Emerging within IGRA Professional Organizations in East Kalimantan. Dinamika Ilmu, 21(1), 7188. DOI: 10.21093/di.v21i1.3061.

Shihab, M. Q. (1996). Wawasan Al-Quran: Tafsir Tematik atas Pelbagai Persoalan Umat. 
Mizan Pustaka.

Subhan, M. (2017). Kepemimpinan Islami Dalam Meningkatkan Mutu Lembaga Pendidikan Islam. MISYKAT: Jurnal Ilmu-Ilmu Al-Quran, Hadist, Syari'ah Dan Tarbiyah, 2(2), 131. https://doi.org/10.33511/misykat.v2n2.131-154

Sutisna, Oeteng. (1989). Administrasi Pendidikan Dasar Teoritis Untuk Praktek Profesional. PT Angkasa

Taufikin. (2021). Pesantren as the Three Centers of Education Perspective of Ki Hadjar Dewantara. Dinamika Ilmu. 21(1), 101-136. DOI: 10.21093/di.v21i1.3149.

Ushansyah, U. (2016). Kepemimpinan Lembaga Pendidikan Islam. ITTIHAD, 14(26).

Yamani, M. T. (2015). Memahami Al-Qur' an dengan Metode Tafsir Maudhu'i. J-Pai, 1(2), 283.https://media.neliti.com/media/publications/321427-memahami-al-qurandengan-metode-tafsir-m-fcbe24bo.pdf

Zuhdi, M. H. (2014). Konsep Kepemimpinan dalam Perspektif Islam. AKADEMIKA: Jurnal Pemikiran Islam, 19(1), 35-57. 